\section{An easy method to determine the serotonin content of human platelets}

\author{
P. F. CROSTI AND P. E. LUCCHELlI From the \\ Istituto di Clinica Medica Generale e di Terapia \\ Medica of the University of Milan
}

The functional significance of serotonin (5HT) is still obscure and its tissue concentration is not constant. Carcinoid is the typical condition in which the serotonin content is very high and variable, but probably in many other pathological or physiological conditions the 5HT concentration is modified. Under the influence of certain drugs the serotonin content in tissues undergoes certain variations, which are claimed to be the basis of their mode of action.

The amount of serotonin can be measured directly in the different tissues of laboratory animals but in man this is clinically possible only with blood. This determination, however, is of interest, since the 5HT content of blood usually varies in the same direction as in other tissues, perhaps functionally more important.

Serotonin in human blood is present in a very low concentration (about $0.1 \mu \mathrm{g} . / \mathrm{ml}$.) and is difficult to determine even with special methods (Waalkes, 1959), but as blood serotonin is almost entirely contained in platelets, their isolation provides a means of concentrating the amine. A simple method suitable for clinical research is presented here.

\section{TECHNIQUE}

Platelet-rich plasma is prepared from 3 to $5 \mathrm{ml}$. of blood by the Dillard technique (Dillard, Brecher, and Cronkite, 1951), modified by the use of larger quantities of EDTA solution (about $30 \%$ ). The thrombocytes are then counted, using white cell pipettes and a Bürker counting cell. After determining the platelet concentration (very constant in our experimental conditions) and the volume of the suspension, the absolute number of thrombocytes is easily obtainable. Platelets are then spun down at $1,600 \mathrm{~g}$ for $20 \mathrm{~min}$. at 0 to $4^{\circ} \mathrm{C}$; the supernatant is discarded and the platelets can be stored in a deep-freezer.
Serotonin is determined by a modification of the Weissbach method (Weissbach, Waalkes, and Udenfriend, 1958). Distilled water up to $1 \mathrm{ml}$. is added to the button of platelets, which is thoroughly resuspended. Then $\mathbf{0 . 2}$ ml. of a $10 \%$ solution of $\mathrm{Zn} \mathrm{SO}_{4} .7 \mathrm{H}_{2} \mathrm{O}$ is added, followed, after briefly shaking, by $0.1 \mathrm{ml}$. of $\mathrm{M} \mathrm{NaOH}$. After vigorous shaking for one minute, the test-tubes are centrifuged at $1,600 \mathrm{~g}$ for $15 \mathrm{~min}$., when $0.5 \mathrm{ml}$. of the water-clear supernatant is put in a test-tube, $0.15 \mathrm{ml}$. of concentrated $\mathrm{HCl}$ is added, and serotonin fluorescence is checked at a spectrophotofluorometer (activation $295 \mathrm{~m} \mu$,

TABLE I

SEROTONIN LEVEL IN 18 NORMALS

\begin{tabular}{|c|c|c|c|}
\hline $\begin{array}{l}\text { Subject } \\
\text { No. }\end{array}$ & $\begin{array}{l}\text { Determination } \\
\text { No. }\end{array}$ & $\begin{array}{l}S H T \\
\left(\mu g / 10^{\circ} \text { platelets }\right)\end{array}$ & Average \\
\hline 1 & $\begin{array}{l}1 \\
2 \\
3 \\
4\end{array}$ & $\begin{array}{l}0.33 \\
0.31 \\
0.32 \\
0.31\end{array}$ & 0.32 \\
\hline 2 & $\begin{array}{l}5 \\
6 \\
7 \\
8\end{array}$ & $\begin{array}{l}1.03 \\
1.07 \\
1.05 \\
1.07\end{array}$ & 1.05 \\
\hline 3 & $\begin{array}{r}9 \\
10 \\
11\end{array}$ & $\begin{array}{l}0.53 \\
0.55 \\
0.60\end{array}$ & 0.56 \\
\hline 4 & $\begin{array}{l}12 \\
13 \\
14 \\
15\end{array}$ & $\begin{array}{l}0.99 \\
0.93 \\
0.93 \\
0.94\end{array}$ & 0.95 \\
\hline 5 & $\begin{array}{l}16 \\
17 \\
18\end{array}$ & $\begin{array}{l}0 \cdot 76 \\
0 \cdot 78 \\
U \cdot 7 y\end{array}$ & 0.78 \\
\hline 6 & $\begin{array}{l}19 \\
20\end{array}$ & $\begin{array}{l}0.68 \\
0.70\end{array}$ & 0.69 \\
\hline 7 & $\begin{array}{l}21 \\
22\end{array}$ & $\begin{array}{l}0.62 \\
0.67\end{array}$ & 0.64 \\
\hline 8 & $\begin{array}{l}23 \\
24\end{array}$ & $\begin{array}{l}0.23 \\
0.23\end{array}$ & 0.23 \\
\hline 9 & $\begin{array}{l}25 \\
26\end{array}$ & $\begin{array}{l}0.49 \\
0.55\end{array}$ & 0.52 \\
\hline 10 & $\begin{array}{l}27 \\
28\end{array}$ & $\begin{array}{l}0.66 \\
0.72\end{array}$ & 0.69 \\
\hline 11 & $\begin{array}{l}29 \\
30\end{array}$ & $\begin{array}{l}0.46 \\
0.36\end{array}$ & 0.41 \\
\hline 12 & $\begin{array}{l}31 \\
32\end{array}$ & $\begin{array}{l}0.48 \\
0.45\end{array}$ & 0.47 \\
\hline 13 & $\begin{array}{l}33 \\
34\end{array}$ & $\begin{array}{l}0.98 \\
1 \cdot 11\end{array}$ & 1.04 \\
\hline $\begin{array}{l}14 \\
15 \\
16 \\
17 \\
18\end{array}$ & $\begin{array}{l}35 \\
36 \\
37 \\
38 \\
39\end{array}$ & $\begin{array}{l}0.46 \\
0.70 \\
1.08 \\
0.55 \\
0.58\end{array}$ & $\begin{array}{l}0.46 \\
0.70 \\
1.08 \\
0.55 \\
0.58\end{array}$ \\
\hline
\end{tabular}

TABLE II

\begin{tabular}{|c|c|c|c|c|}
\hline \multirow[t]{2}{*}{ Authors } & \multirow[t]{2}{*}{ Method } & \multirow{2}{*}{$\begin{array}{l}\text { No. of } \\
\text { Cases }\end{array}$} & \multicolumn{2}{|c|}{ Platelet Serotonin } \\
\hline & & & $\mu g / 10^{\circ}$ & Variability \\
\hline $\begin{array}{l}\text { Hardisty and Stacey (1955) } \\
\text { Zucker and Borrelli (1955) } \\
\text { Schmid et al. (1960) } \\
\text { Weiner and Udenfriend (1957) } \\
\text { Crosti and Bianchi (1959) } \\
\text { Crosti, Bianchi and Lucchelli (1960) } \\
\text { Bianchi, Crosti, and Lucchelli (1960) } \\
\text { Present paper }\end{array}$ & $\begin{array}{l}\text { Biological } \\
\text { Biological } \\
\text { Biological } \\
\text { Spectrophotofluorometry (Udenfriend et al., 1955) } \\
\text { Spectrophotofluorometry (Udenfriend et al., 1955) } \\
\text { Spectrophotofluorometry (Udenfriend et al., 1955) } \\
\text { Spectrophotofluorometry (Udenfriend et al., 1955) } \\
\text { Spectrophotofluorometry }\end{array}$ & $\begin{array}{r}35 \\
100 \\
94 \\
8 \\
19 \\
11 \\
18\end{array}$ & $\begin{array}{l}0.57 \\
0.76 \\
0.73 \\
0.87 \\
0.57 \\
0.57 \\
0.59 \\
0.65\end{array}$ & $\begin{array}{l} \pm 0.18 \text { (S.D.) } \\
\pm 0.04 \text { (S.E.) } \\
\pm 0.09 \text { (S.E.) } \\
\pm 0.05 \text { (S.E.) } \\
\pm 0.06 \text { (S.E.) } \\
\pm 0.06 \text { (S.E.) }\end{array}$ \\
\hline
\end{tabular}

Received for publication 26 August 1961. 


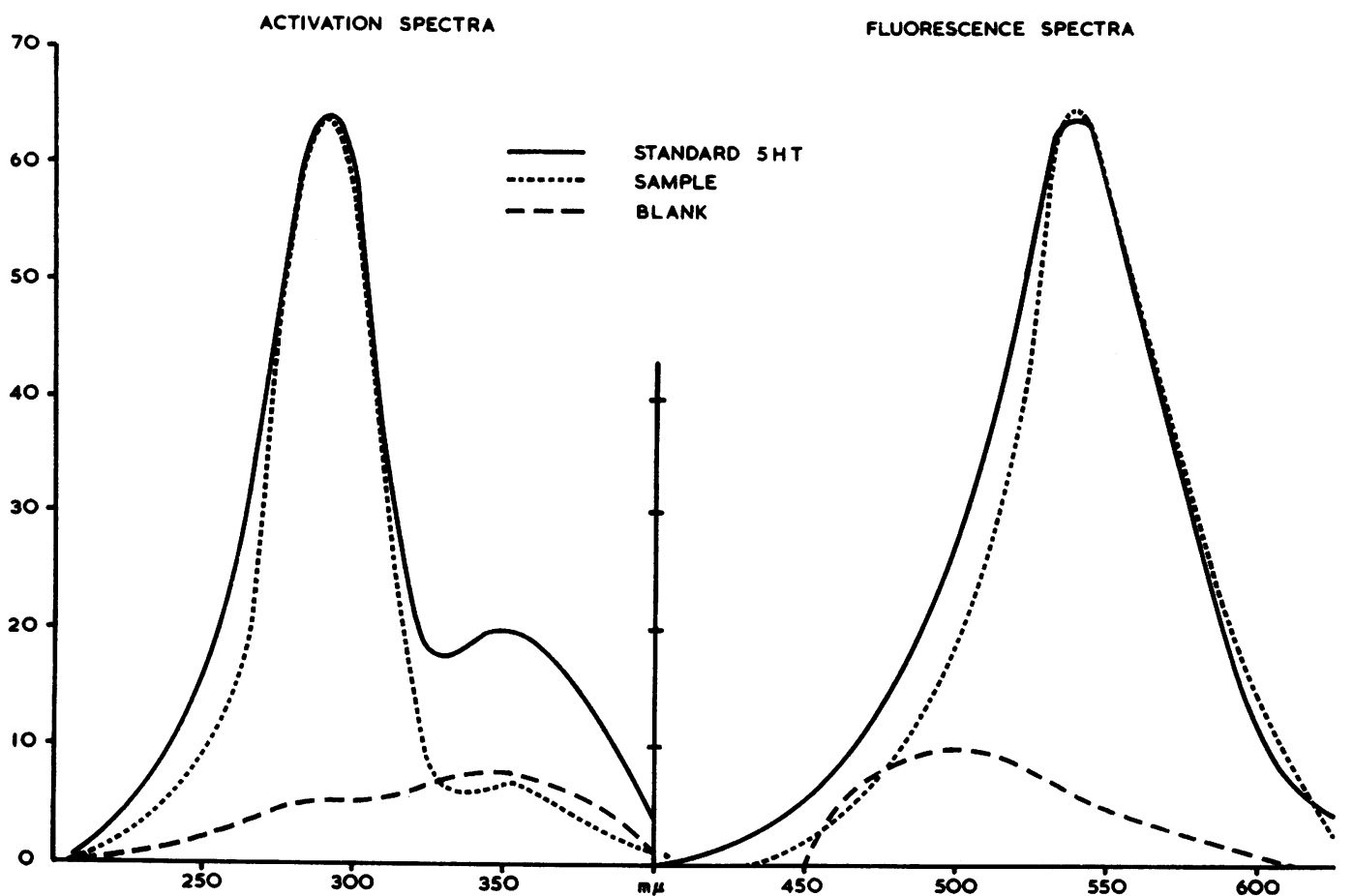

FIG. 1. Activation and fuorescence spectra of extracted serotonin compared with those of a standard solution of $5 H T$

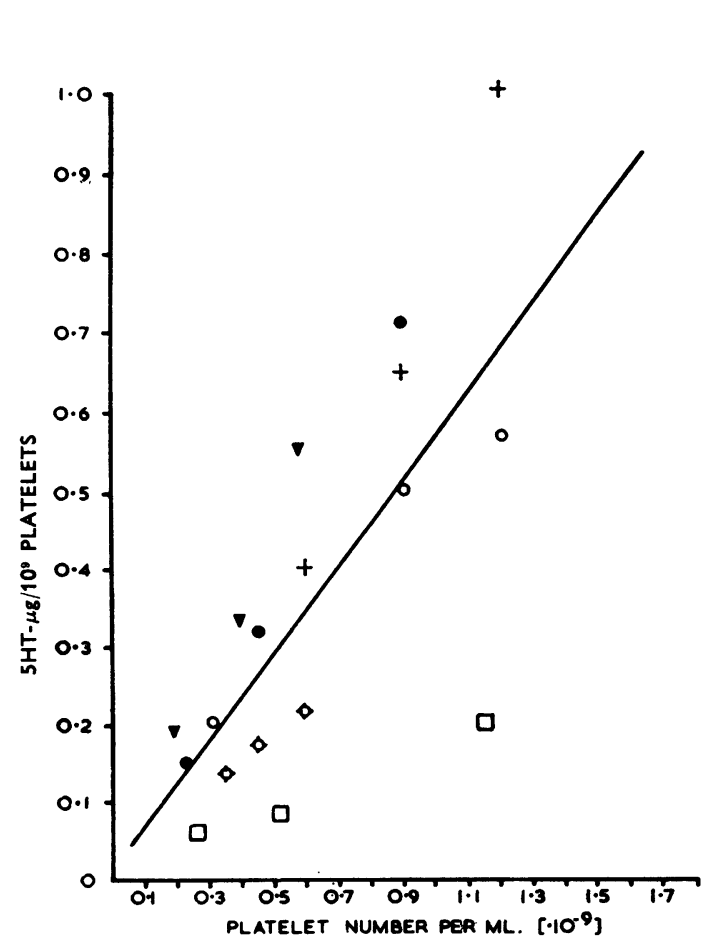

FIG. 2

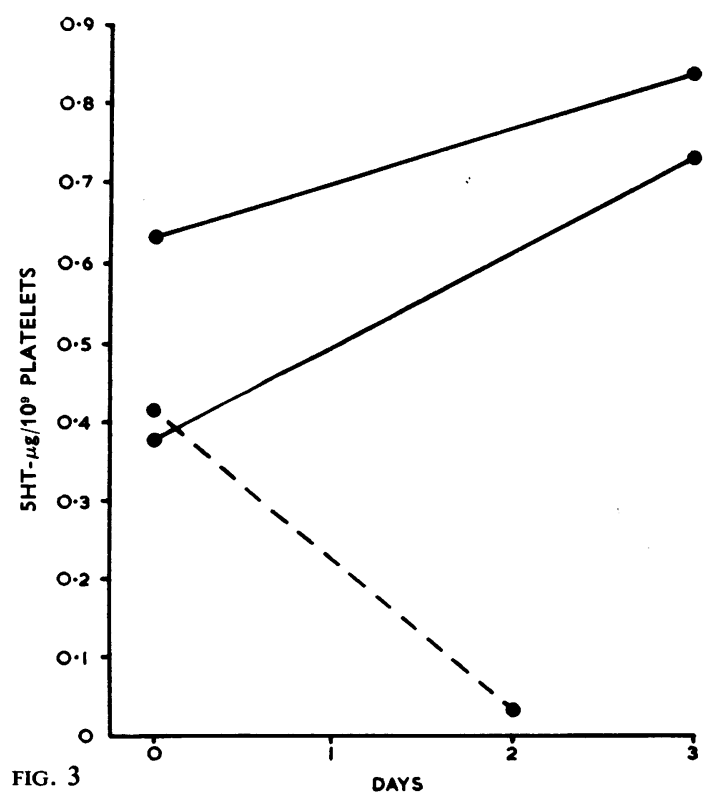

FIG. 3

FIG. 2. Correlation between number of platelets and $5 H T$ extracted.

FIG. 3. Serotonin content of platelets after iproniazid, $150 \stackrel{\mathrm{D}}{\mathrm{Q}}$ mg./day (-) and syrosingopine, $12.5 \mathrm{mg}$. intravenously (-...-) 
fluorescence $540 \mathrm{~m} \mu)$. A blank (1 ml. of distilled water) and one or more standards $(1 \mathrm{ml}$. of a $0.5 \mu \mathrm{g} . / \mathrm{ml}$. solution of $5 \mathrm{HT}$ base) are run throughout the procedure.

\section{RESULTS}

The compound extracted from the platelets shows the same fluorescent characteristics as pure serotonin (Fig. 1) and are known to be highly specific (Weissbach et al., 1958). There is a good correlation between the number of platelets and 5HT extracted, in the range considered (Fig. 2). Table I shows the serotonin level per $10^{\circ}$ platelets in 18 normal subjects.

In Table II the average values and variability obtained by our findings are compared with those described by other authors, using different methods.

\section{DISCUSSION}

The method described is based on two facts: 1 , the highly specific fluorescent characteristics of serotonin, which make its isolation in tissues containing a high level of this substance unnecessary, and 2 , blood serotonin is concentrated in platelets. This procedure does not determine free plasma serotonin, which is generally considered to be extremely low, even in carcinoid (Robertson and Andrews, 1961). The obtained results agree well with those already described in the literature.

Platelet serotonin has often been evaluated by the method of Udenfriend, Weissbach, and Clark (1955), but the procedure is tedious and the amount of blood required relatively high (about $20 \mathrm{ml}$.).

Both these disadvantages seem to be overcome by our method. The facility with which it can be carried out, the short time and the small amount of blood necessary, and the possibility of running many samples at the same time make this procedure particularly suitable for clinical research. The reliability of the method is also shown by the study of platelet serotonin modifications after administration of iproniazid or Rauwolfia alkaloids (Fig. 3). These variations are in agreement with those detected by other methods and reported in the literature.

\section{REFERENCES}

Bianchi, P. A., Crosti, P. F., and Lucchelli, P. E. (1960). Progr. med. (Napoli), 16, 174.

Crosti, P. F., and Bianchi, P. A. (1959). Atti XXI Congr. naz. Cardiol., 2, 139.

- Bianchi, P. A., and Lucchelli, P. E. (1960). Haemat. lat. (Milano), 3, 160.

Dillard, G. H. L., Brecher, G., and Cronkite, E. P. (1951). Proc. Soc. exp. Biol. (N.Y.), 78, 796.

Hardisty, R. M., and Stacey, R. S. (1955). J. Physiol. (Lond.), 130, 711.

Robertson, J. I. S., and Andrews, T. M. (1961). Lancet, 1, 578.

Schmid, E., Scheiffarth, F., Zicha, L., and Siede, H. (1960). Z. ges. exp. Med., 133, 1.

Udenfriend, S., Weissbach, H., and Clark, C. T. (1955). J. biol. Chem., $215,337$.

Waalkes, T. P. (1959). J. Lab. clin. Med., 53, 824.

Weiner, M., and Udenfriend, S. (1957). Circulation, 15, 353.

Weissbach, H., Waalkes, T. P., and Udenfriend, S. (1958). J. biol. Chem., 230, 865.

Zucker, M. B., and Borrelli, J. (1955). J. appl. Physiol., 7, 425.

\section{Book reviews}

M.R.C. Spec. Rep. Ser. med. Res. Coun. (Lond.), No. 300. CEREBRAL INFARCTION: THE ROLE OF STENOSIS OF THE eXtracranial cerebral arteries By Peter O. Yates and Edward C. Hutchinson. (Pp. viii $+95+$ index; 20 plates + many diagrams. 14s.) London: Her Majesty's Stationery Office. 1961.

This special report presents in extended detail the material upon which the authors' well-known papers on carotico-vertebral stenosis are based. There can be no doubt that this work has been of great importance in directing the attention of both pathologists and clinicians to the arteries in the neck-so long and so inexplicably neglected as they were.

There are naturally some features open to criticism. The group of cases on which the report is based has a very mixed structure and it is therefore doubtful if some of the analyses to which the group is subjected have any real significance. The assumption that certain arbitrary degrees of arterial stenosis are 'significant' without serious consideration of the haemodynamic problems involved seems unjustified. Definitions of stenosis are not always clear and it is a pity that differing standards were used for the intracranial (p. 11) and the extracranial (p. 16) arteries. At least one reader is left in doubt as to the meaning of such expressions as 'narrowing of the lumen of any degree up to three quarters'. Surely, also, it is an overstatement to say (p. 14) that intramural vessels 'usually' arise from the lumen: most workers have regarded this as the exception rather than the rule.

The most serious criticism of this study, however, is the absence of any satisfactory control group: it is surely essential as a baseline to know the incidence of caroticovertebral disease in a group of subjects of similar age and in whom there is no evidence of ischaemic cerebral disease, and the absence of such a control group has already led to challenge of the conclusions from one quarter.

The importance of the work, however, remains. There are few who can claim, as these authors can, to have changed post-mortem technique; for it is now obvious that any pathologist who fails to examine the caroticovertebral system in a case of ischaemic cerebral disease is neglecting an important part of the necropsy.

T. CRAWFORD

FEARON'S INTRODUCTION TO BIOCHEMISTRY, 4th ed. Edited by W. J. E. Jessop. (Pp. viii + 473; illustrated. 30s.) London: William Heinemann.

Because of Fearon's untimely death in 1959, the work has been edited by Professor Jessop, and it is never an easy task to take over another man's structure, especially so here because the design of the work is somewhat unusual. The approach to biochemistry of the earlier editions has been retained: it provides the answers to a number of questions which an intelligent beginner will ask and which remain unanswered in the more orthodox books. Unfortunately, the revision of the text for this edition has not been adequate, and the result shows a lack of balance 